\title{
Miller Class III root coverage with coronary tissue repositioning associate with conjunctive graft
}

\author{
Cobertura radicular Clase III de Miller con reposición de tejido coronario asociado con injerto conjuntiva \\ Recobrimento radicular Classe III de Miller com reposicionamento gengival associado com enxerto conjuntivo
}

\author{
Georgia MARIA GRANJA AURELIANO ${ }^{1}$ \\ Severino Alexandre BARBOSA DA SILVA ${ }^{\mathbf{1}}$ \\ Maria MICHELE VIANA ${ }^{1}$ \\ Jaqueline ALVES DO NASCIMENTO ${ }^{2}$ \\ Jefferson David Melo DE MATOS ${ }^{3}$ \\ Pedro Jacy SANTOS DIAMANTINO ${ }^{3}$ \\ Jozely Francisca MELLO LIMA4 \\ Daniel Sartorelli MARQUES DE CASTRO 5 \\ Marco Antonio BOTTINO 6 \\ John Eversong LUCENA DE VASCONCELOS? \\ 'Graduated in Dentistry, Centro Universitário UNILEÃO, Juazeiro do Norte - CE, Brazil \\ ${ }^{2}$ Postgraduate in Oral Surgery, CISO STUDY, Juazeiro do Norte - CE, Brazil \\ ${ }^{3}$ Postgraduate Student - PhD Program in Restorative Dentistry, Department of Dental Materials and Prosthodontics, \\ Universidade Estadual Paulista Júlio de Mesquita Filho UNESP, São José dos Campos - SP, Brazil \\ ${ }^{4}$ Professor Adjunct, Department of Dentistry, Universidade Federal do Ceará UFC, Sobral - CE, Brazil \\ ${ }^{5}$ Professor of Dental Prosthetics, Department of Dentistry, Centro Universitário Christus - UNICHRISTUS, Fortaleza - CE, Brazil \\ ${ }^{6}$ Full Professor of Postgraduate Program in Restorative Dentistry, Department of Dental Materials and Prosthodontic, São Paulo State University, \\ UNESP, Institute of Science and Technology, São José dos Campos - SP, Brazil \\ ${ }^{7}$ Professor of Oral Implantology, Department of Dentistry, Centro Caririense de Pós-Graduação CECAP, Juazeiro do Norte-CE, Brazil
}

Abstract

Introduction: Gingival Recessions (GR) are understood as processes of apical migration of periodontal tissues in relation to the cementenamel junction, that is, they result in an inadequate positioning of the periodontium of protection, causing the consequent root exposure of the dental elements involved. Objective: The present study aims to report a case of Miller class III root coverage with coronary tissue repositioning associate with conjunctive graft. Case Report: A 50-year-old male, leucoderma, normossemic, sought care in a private clinic and presented as the main complaint the root exposition in element 41. After anamnesis, and before an accurate clinical examination and panoramic radiographic the presence of Miller's class III gingival recession, located on the buccal surface of the dental element 41 , was diagnosed. The etiological factor includes a chronic periodontitis associated with bacterial plaque. Discussion: Regarding the collection of palatal connective tissue to be used as an autogenous graft material, the surgical technique adopted in this present case report provides a flap of adequate blood supply, whose nutrition will occur through the connective tissue and periosteum remnant of the surgical site of the recipient. Conclusion: The adopted therapeutic approach comprises a surgical technique of relative ease of execution, which seeks to minimize the postoperative discomfort of the patient and the existence of postoperative complications.

Descriptors: Periodontics; Guided Tissue Regeneration; Dentistry; Surgery Oral.

\section{Resumo}

Introdução: As Recessões Gengivais (RG) são entendidas como processos de migração apical de tecidos periodontais em relação à junção cemento-esmalte, ou seja, resultam em um posicionamento inadequado do periodonto de proteção, ocasionando a conseqüente exposição radicular dos elementos dentários envolvidos. Objetivos: Apresentar um relato de caso acerca de recobrimento radicular classe III de Miller com reposicionamento gengival associado com enxerto conjuntivo. Relato de caso: Paciente do sexo masculino, 50 anos, leucoderma, normossêmico, procurou atendimento em clínica particular e apresentou como queixa principal a exposição da raiz no elemento 41. Após anamnese, exame clínico acurado e tomada radiografica panorâmica, verificou-se a presença de recessão gengival classe III de Miller, localizada na face vestibular do elemento dentário 41. O fator etiológico inclui uma periodontite crônica associada à placa bacteriana. Discussão: Em relação à coleta do tecido conjuntivo palatino para ser usado como material de enxerto autógeno, a técnica cirúrgica adotada neste relato de caso fornece um retalho de suprimento sanguíneo adequado, cuja nutrição ocorrerá através do tecido conjuntivo e do periósteo remanescente do sítio cirúrgico do destinatário. Conclusão: A abordagem terapêutica adotada compreende uma técnica cirúrgica de relativa facilidade de execução, que busca minimizar o desconforto pós-operatório do paciente e a existência de complicações pós-operatórias.

Descritores: Periodontia; Regeneração Tecidual Guiada; Odontologia; Cirurgia Oral.

\section{Resumen}

Introducción: las recesiones gingivales (GR) se entienden como procesos de migración apical de los tejidos periodontales en relación con la unión cemento-esmalte, es decir, dan como resultado un posicionamiento inadecuado del periodonto de protección, lo que provoca la consiguiente exposición radicular de los elementos dentales. Involucrado. Objetivos: Presentar un estudio con el objetivo de relatar un caso de cobertura radicular clase III de Miller con reposición de tejido coronario asociado con injerto conjunctiva. Caso Clinico: Varón de 50 años, leucoderma, normosémico, buscó atención en una clínica privada y presentó como principal queja la exposición de la raíz en el elemento 41. Después de la anamnesis, y antes de un examen clínico preciso y radiográfico panorámico, fue diagnosticado la recesión gingival de clase III de Miller, ubicada en la superficie bucal del elemento dental 41. El factor etiológico incluye una periodontitis crónica asociada a placa bacteriana. Discusion: Con respecto a la colección de tejido conjuntivo palatino que se utilizará como material de injerto autógeno, la técnica quirúrgica adoptada en el presente informe de caso proporciona un colgajo de suministro de sangre adecuado, cuya nutrición se producirá a través del tejido conjuntivo y el resto del periostio del sitio quirúrgico del receptor. Conclusión: el abordaje terapéutico adoptado comprende una técnica quirúrgica de relativa facilidad de ejecución, que busca minimizar las molestias postoperatorias del paciente y la existencia de complicaciones postoperatorias.

Descriptores: Periodoncia; Regeneración de tejidos guiados; Odontología; Cirugía Oral.

\section{INTRODUCTION}

Gingival Recessions (GR) are understood as processes of apical migration of periodontal tissues in relation to the cement-enamel junction, that is, they result in an inadequate positioning of the periodontium of protection, causing the consequent root exposure of the dental elements involved; which corroborates with the existence of aesthetic problems, the propensity for the appearance of root caries, and an increase in the thermal and tactile dental sensibility. This condition has several etiological 
factors, such as anatomical variations, occlusal alterations, periodontal diseases, inappropriate dental brushing, or due to deleterious habits, as well as iatrogenic causes arising from restorative and / or periodontal procedures ${ }^{1-3}$. In order to obtain correct diagnoses and prognoses, in addition to an adequate treatment plan for each patient, classification of gingival recess is essential, being Miller's classification $^{4}$ the most widely used, although some limitations are found. In this system, the mucogingival junction (MGJ), which consists of the transition area between the inserted gingiva and the alveolar mucosa, and the alveolar bone crest are the parameters used for the four classes of gingival recess 5 .

In class I, there are cases in which interdental bone loss or interdental papilla involvement are absent, and marginal tissue recession is below the mucogingival junction; in class II, there is also no involvement of the interdental bone or papilla, but the recession of the gingival tissue reaches or exceeds the MGJ. In classes III and IV, loss of interdental papilla and interdental bone tissue occurs, and in both, the marginal tissue recession is beyond the mucogingival junction. The difference lies in the fact that, in class III, the loss of interdental papilla or bone tissue is coronary position to the recession of the marginal tissue, whereas in class IV, it is located apically or at the same level of the recession ${ }^{4}$.

The determination of an appropriate therapeutic approach for gingival recessions is associated with an accurate analysis of the etiological factors as well as the amount and extent of periodontal tissue involved. Thus, the existence of localized or generalized multiple or isolated defects, height and width of the gingival recession, level of clinical insertion, and amount of keratinized tissue present in the inserted gingiva are crucial aspects for the management of gingival recess ${ }^{6}$.

Recent studies indicate that lateral or coronary repositioning of the tissue flap, concomitant or not with the use of free or subepithelial autogenous gingival graft materials, dermal tissue allograft and various types of membranes for guided tissue regeneration, present excellent treatment results of defects Miller's class I and II $^{7-9}$.

Vestibular flap coronary advancement, associated with the placement of a subepithelial graft of autogenous palatine origin, represents an effective alternative to interrupt the progression of tissue loss, and resolve aesthetic complaints and relief of painful symptomatology presented in cases of gingival recessions. Moreover, in this surgical technique, graft material coverage by the advanced flap provides better vascularization and, therefore, an increase in graft survival ${ }^{9}$.

After the healing process, an efficient root coverage is obtained in areas of gingival recession surgically treated with pedicular, coronary advanced or laterally displaced flaps, but the formation of a long junctional epithelium between the root surface and the adjacent periodontal tissue, demonstrates the inexistence of a satisfactory periodontal fixation apparatus, the achievement of which would be possible through the insertion of connective tissue fibers ${ }^{10}$.

The collection of autogenous palatine grafts results in an increase in the number of surgical sites, corresponding to a donor and a recipient area, which results in a longer time required in the surgical procedure, discomfort to the patient, and greater risks of paresthesia, changes in donor site sensitivity, necrosis, infectious processes, bleeding and damage to the major palatine artery. However, the achievement of an ideal palatal subepithelial connective graft, through established clinical requirements, is aimed at achieving stability of the gingival profile, with significant aesthetic and functional improvements in areas of apical migration of marginal gingival tissues ${ }^{11-13}$.

The present study describes a clinical case report of root coverage with coronary repositioning of vestibular flap allied to the placement of autogenous palate subepithelial graft, as a surgical approach for treatment of unitary gingival recession.

\section{CLINICAL CASE}

A 50-year-old male, leucoderm, normossemic patient, sought care in a private clinic and presented as the main complaint the root exposition in element 41. After anamnesis, and before an accurate clinical examination and panoramic radiographic the presence of Miller's class III gingival recession, located on the buccal surface of the dental element 41, was diagnosed. The etiological factor includes a chronic periodontitis associated with bacterial plaque (Figure 1).

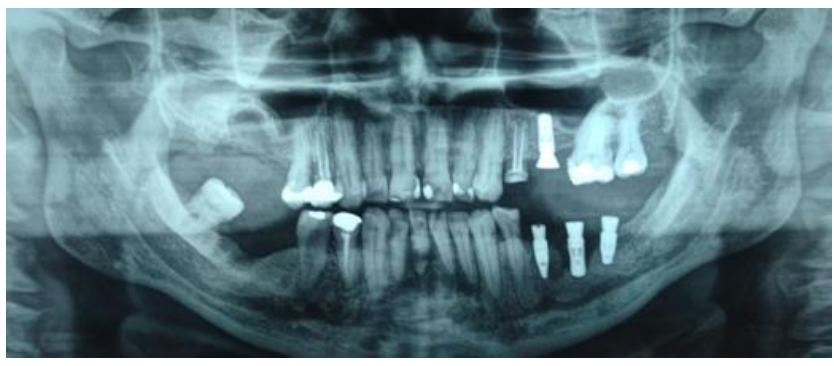

Figure 1: Panoramic radiograph of the jaws, evidencing the presence of Miller's class III gingival recession, located on the buccal surface of the dental element 41 .

The patient was submitted to a pre-surgical phase of oral adjustment, which included guidelines and motivation for oral hygiene, as well as clinical sessions for scraping and supragingival and subgengival coronorradicular straightening. After reevaluation of the first phase of periodontal treatment, low levels of gingival bleeding and dental biofilm were observed, thus facilitating the 
subsequent execution of the root canal surgical procedure with coronary placement of the vestibular flap, together with the use of the autogenous subepithelial palatal graft.

In order to obtain the anesthetic block of the major palatine nerve, in the donor area of the palate, the terminal branches of the lingual nerve, and the right and left mental nerves, at the surgical site, $2 \%$ lidocaine with 1: 100,000 epinephrine was used. Initially, a vestibular intrassucular incision was made that extended from the distal region of element 43 to the distal of tooth 33 , followed by detachment of the flap and consequent exposure of the anterior mandibular region, through which intraoperative measurements were obtained with the aid of a periodontal catheter. Therefore, it became possible to analyze the necessary dimensions of connective tissue to be collected from the palate in order to cover the gingival defects previously encountered.

In the palate, a horizontal incision was made, preserving the integrity of the interdental papillae, in the region corresponding to the first premolar and second right molar. A partial flap of connective tissue was sectioned from the mucoperiosteal flap of the envelope type, using scalpel $15 \mathrm{c}$ and a forceps for tissue seizure, keeping the palatal epithelial tissue intact. After collection of autogenous graft material, the donor surgical site was sutured with 4-0 nonresorbable monofilament yarn (Figure 2).

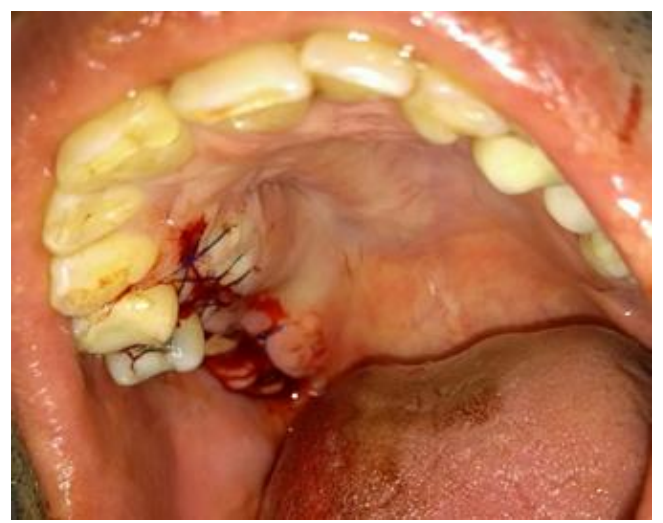

Figure 2: Horizontal incision on the palate in the region corresponding to the first premolar and second right molar to remove subepithelial tissue and suture with 4-0 non-resorbable monofilament yarn.

The root conditioning of the dental element 31 was performed using PrefGel Straumann ${ }^{\circledR}$ (Fig.III), removed with abundant irrigation after 2 minutes, and followed by the application of Emdogain Straumann ${ }^{\circledR}$ (Fig.IV) on the entire surface of the exposed dental root, from the most apical portion of the bone defect found. The palatal connective graft was then carefully positioned over the receptor site in the lower central incisor region, beyond the cementum-enamel junction, while the obtained vestibular flap was repositioned coronally, partially covering the subepithelial graft. Sutures with resorbable, colorless and monofilament yarn 5.0 were used to anchor the grafting tissue to the adjacent dental elements, unlike the advanced coronal flap, which was stabilized by interrupted stitches with nonresorbable suture yarn next to the bloody tissues in the interdental papilla region (Figure 5).

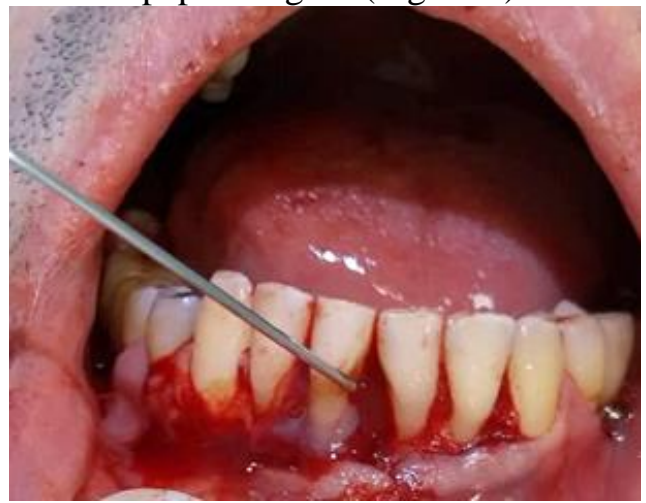

Figure 3: Root conditioning of dental element 31 performed using PrefGel Straumann®.

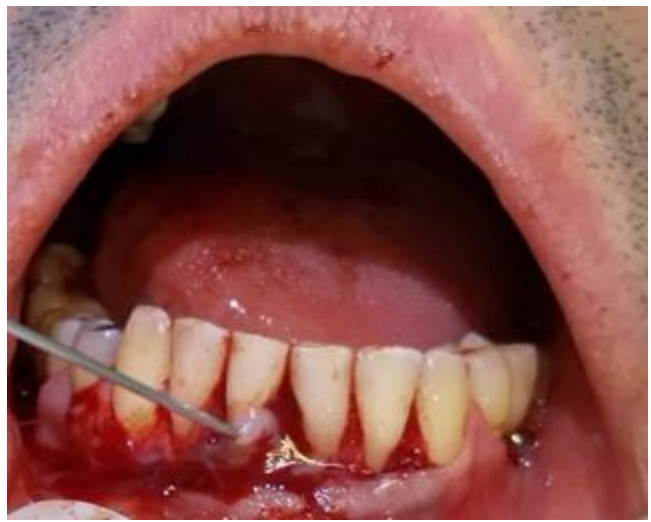

Figure 4: Application of Emdogain Straumann ${ }^{\circledR}$ on the entire surface of the exposed dental root, from the most apical portion of the bone defect found.

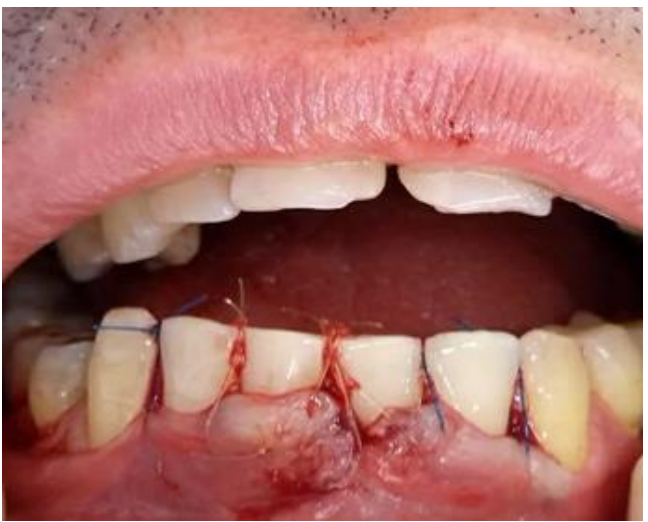

Figure 5: Sutures with reabsorbable, colorless and monofilament yarn 5.0 anchoring the grafting tissue to the adjacent dental elements. And 4-0 wire in the advanced coronal flap with interrupted stitches next to the bloody tissues in the interdental papilla region.

DISCUSSION

Several surgical procedures of periodontal plastic are used, and innovations of techniques and materials are constantly elaborated in order to obtain efficient forms of treatment for root exposure due to recession of marginal gingival tissue ${ }^{14}$.

In a randomized controlled clinical trial, which objective was to analyze the benefits of the use of palatal connective tissue grafts, combined with surgical dressing and tissue flap coronary advancement, to treat single gingival recessions in 
the maxilla, a total of 29 patients composed the sample, of which 15 subjects received the grafting material, while the others were submitted only to the repositioning surgery of the flap. After six months, the group of patients who received connective tissue grafts had better total root coverage results when compared to the other group analyzed in this clinical study. However, the group of individuals submitted to graft flap advancement also presented longer surgical time, greater postoperative morbidity and greater need for analgesic medication ${ }^{15}$.

Regarding the collection of palatal connective tissue to be used as an autogenous graft material, the surgical technique adopted in this present case report provides a flap of adequate blood supply, whose nutrition will occur through the connective tissue and periosteum remnant of the surgical site of the recipient. In addition, palatal healing is obtained by first intention, which consequently causes a lower rate of morbidity to the patient, since the donor area is sutured soon after the acquisition of a mucosal flap from a mucoperiosteal flap of total thickness. Therefore, it presents a better clinical prognosis to the detriment of the application of graft collection techniques that leave the donor site uncovered or without epithelium, with the presence of bloody tissue, which closure will occur in a secondary way, causing greater discomfort to the patient $^{16-20}$.

The application of PrefGel and Emdogain Straumann ${ }^{\circledR}$ in the area of the connective graft aims to stimulate the process of periodontal regeneration, with consequent formation of cementum, periodontal ligament and alveolar bone, through the activity of enamel matrix derived proteins, which are also related to a greater amount of keratinized tissue formation in the long term. Therefore, tissue healing of the surgical site with the appearance of a long junctional epithelium is avoided, which is associated with the occurrence of an ineffective periodontal fixation apparatus after root coverage procedures ${ }^{21-24}$.

\section{CONCLUSION}

It can be concluded from this study that the adopted therapeutic approach comprises a surgical technique of relative ease of execution, which seeks to minimize the postoperative discomfort of the patient and the existence of postoperative complications, resulting in a positive impact on the quality of life related to oral health once obtained the root coverage and periodontal regeneration of the dental element affected by gingival recession.

\section{REFERENCES}

1. Jenabian N, Motallebnejad M, Zahedi E, Sarmast ND, Angelov N. Coronally advanced flap and connective tissue graft with or without plasma rich in growth factors (PRGF) in treatment of gingival recession. J Clin Exp Dent. 2018;10(5):e431-38.

2. Rehan M, Khatri M, Bansal M, Puri K, Kumar A. Comparative Evaluation of Coronally Advanced Flap Using Amniotic Membrane and Platelet-rich Fibrin Membrane in Gingival Recession: An 18Month Clinical Study. Contemp Clin Dent. 2018;9(2):188-94.

3. Pini Prato GP, Franceschi D, Cortellini P, Chambrone L. Long-term evaluation (20 years) of the outcomes of subepithelial connective tissue graft plus coronally advanced flap in the treatment of maxillary single recession-type defects. J Periodontol. 2018;89(11):1290-1299.

4. Miller PD Jr. A classification of marginal tissue recession. Int J Periodontics Restorative Dent. $1985 ; 5(2): 8-13$.

5. Guttiganur N, Aspalli S, Sanikop MV, Desai A, Gaddale R, Devanoorkar A. Classification systems for gingival recession and suggestion of a new classification system. Indian J Dent Res. 2018;29(2):233-37.

6. Rasperini G, Acunzo R, Pellegrini G, Pagni G, Tonetti M, Pini Prato GP et al. Predictor factors for long-term outcomes stability of coronally advanced flap with or without connective tissue graft in the treatment of single maxillary gingival recessions: 9 years results of a randomized controlled clinical trial. J Clin Periodontol. 2018;45(9):1107-17.

7. Trombelli L, Simonelli A, Minenna L, Rasperini G, Farina R. Effect of a Connective Tissue Graft in Combination With a Single Flap Approach in the Regenerative Treatment of Intraosseous Defects. J Periodontol. 2017;88(4):348-56.

8. Tavelli L, Barootchi S, Nguyen TVN, Tattan M, Ravidà A, Wang HL. Efficacy of tunnel technique in the treatment of localized and multiple gingival recessions: A systematic review and metaanalysis. J Periodontol. 2018;89(9):1075-1090.

9. George SG, Kanakamedala AK, Mahendra J, Kareem N, Mahendra L, Jerry JJ. Treatment of gingival recession using a coronally-advanced flap procedure with or without placental membrane. J Investig Clin Dent. 2018;9(3):e12340.

10. Ramireddy S, Mahendra J, Rajaram V, Ari G, Kanakamedala AK, Krishnakumar D. Treatment of gingival recession by coronally advanced flap in conjunction with platelet-rich fibrin or resinmodified glass-ionomer restoration: A clinical study. J Indian Soc Periodontol. 2018;22(1):45-49.

11. Akram Z, Vohra F, Javed F. Low-level laser therapy as an adjunct to connective tissue graft procedure in the treatment of gingival recession defects: A systematic review and meta-analysis. J Esthet Restor Dent. 2018;30(4):299-306. 
12. Francetti L, Taschieri S, Cavalli N, Corbella S. Fifteen-Year Follow-Up of a Case of Surgical Retreatment of a Single Gingival Recession. Case Rep Dent. 2018;2018:3735162.

13. Cairo F, Cortellini P, Tonetti M, Nieri M, Mervelt J, Pagavino $G$ et al. Stability of root coverage outcomes at single maxillary gingival recession with loss of interdental attachment: 3-year extension results from a randomized, controlled, clinical trial. J Clin Periodontol. 2015;42(6):575-81.

14. Deepa D, Arun Kumar KV. Clinical evaluation of Class II and Class III gingival recession defects of maxillary posterior teeth treated with pedicled buccal fat pad: A pilot study. Dent Res J (Isfahan). 2018;15(1):11-6.

15. Culhaoglu R, Taner L, Guler B. Evaluation of the effect of dose-dependent platelet-rich fibrin membrane on treatment of gingival recession: a randomized, controlled clinical trial. J Appl Oral Sci. 2018;26:e20170278.

16. Reino DM, Novaes AB Jr, Grisi MF, Maia LP, de Souza SL. Palatal harvesting technique modification for better control of the connective tissue graft dimensions. Braz Dent J. 2013;24(6):565-68.

17. Apicella A, Heunemann P, Bolisetty S, Marascio M, Graf AG, Garamszegi L et al. The Influence of Arginine on the Response of Enamel Matrix Derivative (EMD) Proteins to Thermal Stress: Towards Improving the Stability of EMD-Based Products. PLoS One. 2015;10(12):e0144641.

18. da Silva Neves FL, Silveira CA, Dias SB, Santamaria Junior M, de Marco AC, Kerbauy WD et al. Comparison of two power densities on the healing of palatal wounds after connective tissue graft removal: randomized clinical trial. Lasers Med Sci. 2016;31(7):1371-78.

19. Schmidlin P, Zobrist K, Attin T, Wegehaupt F. In vitro re-hardening of artificial enamel caries lesions using enamel matrix proteins or selfassembling peptides. J Appl Oral Sci. 2016;24(1):31-6.

20. Aguirre-Zorzano LA, García-De La Fuente AM, Estefanía-Fresco $R$, Marichalar-Mendía $X$. Complications of harvesting a connective tissue graft from the palate. A retrospective study and description of a new technique. J Clin Exp Dent. 2017;9(12):e1439-e45.

21. Arweiler NB, Auschill TM, Donos N, Sculean A. Antibacterial effect of an enamel matrix protein derivative on in vivo dental biofilm vitality. Clin Oral Investig. 2002;6(4):205-9.

22. Bhutda G, Deo V. Five years clinical results following treatment of human intra-bony defects with an enamel matrix derivative: a randomized controlled trial. Acta Odontol Scand. 2013; 71(3-4):764-70.
23. Bajić MP, Danilović V, Prokić B, Prokić BB, Manojlović M, Živković S. Histological Effects of Enamel Matrix Derivative on Exposed Dental Pulp. Srp Arh Celok Lek. 2015;143(7-8):397-403.

24. Jaiswal GR, Kumar R, Khatri PM, Jaiswal SG, Bhongade ML. The effectiveness of enamel matrix protein (Emdogain $(\circledR)$ ) in combination with coronally advanced flap in the treatment of multiple marginal tissue recession: A clinical study. J Indian Soc Periodontol. 2012;16(2):224-30.

\section{CONFLICTS OF INTERESTS}

The authors declare no conflicts of interests.

\section{CORRESPONDING AUTHOR}

\section{John Eversong Lucena de Vasconcelos}

D.D.S.; M.D.; Ph.D.

Professor of Oral Implantology, Department of Dentistry, Centro Caririense de Pós-Graduação CECAP, Juazeiro do Norte - CE, Brazil.

Rua Sulino Duda, 113, Triangulo - Juazeiro do Norte - CE CEP $63041-185$.

Telefone: +55 (88) 3512-1590/+55 (88) 9. 9934-1103

jaquelinealves_10@hotmail.com 